\title{
Convergence of diet estimates derived from fatty acids and stable isotopes within individual grey seals
}

\author{
Strahan Tucker $^{1, *}$, W. Don Bowen ${ }^{2}$, Sara J. Iverson ${ }^{1}$ \\ ${ }^{1}$ Department of Biology, Dalhousie University, 355 Oxford Street, Halifax, Nova Scotia B3H 4J1, Canada \\ ${ }^{2}$ Population Ecology Division, Bedford Institute of Oceanography, Department of Fisheries and Oceans, 1 Challenger Drive, \\ Dartmouth, Nova Scotia B2Y 4A2, Canada
}

\begin{abstract}
What animals consume is perhaps one of the most fundamental questions in ecology. Limitations of stomach content and faecal analyses have led to the development of alternative biochemical methods, namely fatty acid (FA) signature analysis and stable isotope (SI) analysis. Proportional estimates of diet composition can be made at the level of the individual by statistically matching a consumer's FA signature to an inclusive prey database, after accounting for predator metabolism effects in a mixing model. Both of these approaches provide inferences about or quantitative estimates of diet that are time-integrated and readily applied to most taxa of interest, thereby alleviating many problems associated with conventional analysis. Moreover, analysis is done at the level of individual predators, thereby increasing our ability to detect differences amongst various demographic groups. However, it is difficult to validate diet estimates from either of these methods in the field, particularly for wide-ranging aquatic predators such as seals or seabirds consuming complex diets. Concurrent sampling of individual predators for both stable isotopes and fatty acids provide 1 such independent test. To that effect, we analyzed SI and FA for grey seals Halichoerus grypus $(\mathrm{n}=75)$ and potential fish and invertebrate prey $(\mathrm{n}=45)$. We show 2 lines of evidence for the convergence of stable isotope and fatty acid estimates of diet. First, in fish, invertebrates and grey seals, principal components derived from fatty acid signatures are correlated to the stable-carbon isotope $\left(\delta^{13} \mathrm{C}\right)$ signature of the same species. Second, both the estimated portion of pelagic prey and the trophic level of the diet derived from the quantitative analysis of fatty acid signatures of individual seals are positively correlated with the stable-carbon $\left(\delta^{13} \mathrm{C}\right)$ and stable-nitrogen $\left(\delta^{15} \mathrm{~N}\right)$ signatures in those same individuals. The corroboration of independent measures of diet provides further validation of these biochemical methods to understand the foraging ecology of consumers.
\end{abstract}

KEY WORDS: Fatty acids · Stable isotopes · Diet estimation · Corroboration · Grey seals

\section{INTRODUCTION}

Accurate quantification of diet is a fundamental requirement for understanding the foraging ecology and energy budgets of free-ranging animals. Limitations of stomach content and faecal analyses (Jobling \& Breiby 1986, Jobling 1987, Bowen \& Siniff 1999) have led to the development of alternative biochemical methods. The 2 main approaches are fatty acid (FA) signature analysis and stable isotope (SI) analysis. Both of these methods provide inferences about or quantitative esti- mates of diet that are time integrated and can be readily applied to many taxa (Kelly 2000, Iverson et al. 2004). In addition, sampling can be done non-lethally, allowing for the study of small populations and of individuals over time. Both methods have been reviewed extensively (e.g. FA: Iverson et al. 2004, Budge et al. 2006; SI: Kelly 2000, Post 2002). The 2 methods are independent: one examines the FA composition of lipid stores, the other examines the isotope ratios of carbon and nitrogen in various tissues or in the whole body of a consumer, and often these samples are lipid extracted. 
The concurrent analysis of stable carbon $\left(\delta^{13} \mathrm{C}\right)$ and nitrogen $\left(\delta^{15} \mathrm{~N}\right)$ isotopes provides a 2-dimensional picture of the dietary space occupied by a consumer relative to other consumers (Post 2002). SIs of nitrogen are enriched in consumers relative to diet by an average of $3.4 \%$, thereby providing a measure of trophic level, although this can be highly variable depending on the ecosystem as well as the specific tissue analyzed (Hobson \& Welch 1992, Hobson et al. 1994, Post 2002). Stable-carbon isotopes remain little changed with trophic transfer, as they enrich by $<1 \%$, and are thus more indicative of sources of primary production (Hobson et al. 1994, France \& Peters 1997, Kelly 2000). Stable-carbon isotopes are known to reflect different sources of primary production and can be used to discriminate between carbon pools or habitats (e.g. terrestrial vs. aquatic, benthic vs. pelagic). For example, in marine systems, the stable-carbon signature increases from negative (depleted) values for pelagic species to more positive (enriched) values for benthic species, while $\delta^{15} \mathrm{~N}$ increases with trophic level within each respective system (Davenport \& Bax 2002, Sherwood \& Rose 2005, Tucker et al. 2007). Analysis of SIs does not easily permit individual prey species to be identified, particularly in more complex food webs. However, SI allow for a standardized comparison among individuals or taxa and can provide temporal integration of diets over different time scales owing to the analysis of multiple tissues with different turnover times (Hobson 1993, Bearhop et al. 2004). The isotopic measurement of several tissues from the same individual can provide short-, intermediate- and long-term dietary information (e.g. Hobson 1993), as turnover of SIs varies with the metabolic activity of the tissue sampled (Tieszen et al. 1983, Hobson \& Clark 1992, Hobson 1993, Lesage et al. 2002). For example, it is thought that the isotopic analysis of metabolically inactive tissues (e.g. hair, skin, whiskers, claws, feathers, baleen) reflects the diet of individuals only during the period of growth (Schell et al. 1989, Hobson et al. 1996). On the other hand, SI values from muscle or blubber integrate dietary information over the course of weeks to months because these tissues have higher turnover rates (Kurle \& Worthy 2001, 2002).

By contrast, FA signature analysis can provide both a qualitative assessment of temporal or spatial changes in diet (e.g. Iverson et al. 1997a,b, Smith et al. 1997) and a quantitative estimate of the species composition of the diet (Iverson et al. 2004, Bowen et al. 2006, Beck et al. 2007). We refer to the proportional distribution of all FAs measured in a consumer as its FA signature. FAs are deposited in animal tissue in a predictable manner and there are limits on polyunsaturated FA biosynthesis in higher order consumers (Iverson 1993). Proportional estimates of diet composition can be made at the level of the individual by statistically matching a consumer's FA signature to an inclusive prey database (Iverson et al. 2004), known as quantitative FA signature analysis (QFASA). As with SI analysis, different tissues analyzed for FAs provide insight into diet over different temporal scales (reviewed in Budge et al. 2006). These include adipose tissue, blubber, milk and blood. Both non-structural adipose tissue and blubber contain lipids that have accumulated over time (weeks to months: Iverson et al. 2004, Budge et al. 2006), while FA composition of chylomicrons in blood represent lipids assimilated in the last meal (Cooper et al. 2005). Thus, analysis of FAs in different tissues can provide dietary information over a period of hours to months.

Both biochemical tracer methods have been validated through feeding experiments (e.g. Kelly 2000, Iverson et al. 2004) and are known to be long-term integrators of the assimilated portion of the diet. The strengths and limitations of the use of SIs to study trophic interactions are rather well understood (Kelly 2000, Post 2002). However, feeding experiments on the use of FAs are fewer in number to date, have generally involved small numbers of animals, were short term and dealt with fairly simple diets (typically $<5$ different prey species). Of course, it is difficult to validate diet estimates from either of these methods in the field, particularly for wide-ranging aquatic predators such as seals or seabirds. However, if these 2 independent methods provide similar views of the diet, then we may have greater confidence in the validity of those estimates.

In the present paper, we compared proportional FA signatures and SI values of potential fish and invertebrate prey species of grey seals Halichoerus grypus from the NW Atlantic and those taken from individual grey seals. We hypothesized that FA signatures characteristic of pelagic or benthic feeding would be correlated with the $\delta^{13} \mathrm{C}$ in potential prey. For example, relatively high levels of $17: 0,18: 1 n-7$ and $20: 4 n-6$ are associated with benthic systems, and high levels of 14:0, 22:1n-11, 20:1n-9, 18:2n-6, 18:3n-3 and 18:4n-3 occur in pelagic systems (Budge et al. 2002, Käkelä et al. 2005). Likewise, we expected to see similar relationships in the FA signatures of grey seals. We subsequently compared the proportional diet estimates derived from QFASA (Beck et al. 2007) with those from the SI signatures derived from skin samples (Tucker et al. 2007) of the same adult grey seals. First, we hypothesized that the proportion of pelagic prey species estimated by QFASA would be correlated to $\delta^{13} \mathrm{C}$. Second, we expected that the integrated trophic level of the QFASA-estimated diet would be correlated to $\delta^{15} \mathrm{~N}$. The diets of grey seals are known to be temporally and spatially variable, as well as complex, as over 60 prey 
items have been identified in stomach contents (Bowen et al. 1993), although individual animals generally consume only a small subset of these species (Beck et al. 2007).

\section{MATERIALS AND METHODS}

Grey seal Halichoerus grypus sampling. The study was conducted on Sable Island $\left(43^{\circ} 55^{\prime} \mathrm{N}, 60^{\circ} 00^{\prime} \mathrm{W}\right)$, a vegetated sandbar approximately $45 \mathrm{~km}$ long, about $300 \mathrm{~km}$ SE off mainland Nova Scotia, Canada. Seals breed on the island in January, return to moult in spring, and haul out on the island periodically at other times of the year (Beck et al. 2003). From 1996 to 2001, we sampled adult grey seals in May and June (females $=14 ;$ males $=10$ ), September and October $($ females $=10$; males $=14)$ and January $($ females $=13$; males $=14$ ) at the start of the breeding season. Individuals were captured onshore using hand-held nets (see Bowen et al. 1992). Skin samples (approximately 0.05 to $0.1 \mathrm{~g}$ ) were taken from the rear flipper. Skin samples were lipid extracted using a modified Folch method (Iverson et al. 2001) and analyzed for SIs of carbon and nitrogen. At the same time, a blubber biopsy was taken of the full depth of the blubber layer from each animal on the posterior flank (Beck et al. 2005, 2007). Data for animals presented in the present study are a subsample of a much broader sampling effort evaluating diet for grey seals over multiple spatial and temporal scales.

Fish and invertebrate prey sampling. Fishes and invertebrates were collected and frozen during stratified, random, bottom-trawl surveys conducted in the summer on the Scotian Shelf (Northwest Atlantic Fisheries Organization Sub-Areas 4V, 4W and 4X) in 2000 and 2001 (see Budge et al. 2002). Three individuals each of 12 fish and 3 invertebrate species were analyzed. Fork length or carapace width was measured to the nearest $0.1 \mathrm{~cm}$, and body mass was determined to the nearest $0.1 \mathrm{~g}$. Each individual was then homogenized. Lipids were quantitatively recovered in duplicate from sub-samples (approximately $1.5 \mathrm{~g}$ ) of the homogenized tissue using a modified Folch method (Iverson et al. 2001). FA profiles were compiled as part of a larger prey database for the NW Atlantic (summarized in Budge et al. 2002). An additional sub-sample (approximately $1.5 \mathrm{~g}$ ) was subsequently analyzed for SIs of carbon and nitrogen.

Stable isotope analysis. SI analyses are presented in Tucker et al. (2007). Briefly, samples were lipid extracted using a modified Folch method (Iverson et al. 2001), dried to constant weight (for $48 \mathrm{~h}$ at $80^{\circ} \mathrm{C}$ in a drying oven) and crushed to a fine powder using a mortar and pestle. Stable carbon and nitrogen isotope ratios of these samples were determined by the analysis of $\mathrm{CO}_{2}$ and $\mathrm{N}_{2}$ produced by combustion in a CE Elemental Analyzer, followed by gas chromatograph separation and analysis with a Delta plus isotope ratio mass spectrometer (G.G. Hatch Isotope Laboratories). Stable carbon and nitrogen ratios were expressed in delta $(\delta)$ notation, defined as the parts per thousand (\%) deviation from a standard material: $\delta^{13} \mathrm{C}$ or $\delta^{15} \mathrm{~N}=$ $\left(\left[R_{\text {sample }} / R_{\text {standard }}\right]-1\right) \times 1000 ; R={ }^{13} \mathrm{C} /{ }^{12} \mathrm{C}$ or ${ }^{15} \mathrm{~N} /{ }^{14} \mathrm{~N}$. Standards used were PDB limestone for $\delta^{13} \mathrm{C}$ and $\mathrm{N}_{2}$ in air for $\delta^{15} \mathrm{~N}$. A sub-sample (8\%) was analyzed in duplicate; the average $\mathrm{SE}$ of the mean for replicates was $0.15 \%$ or $\delta^{13} \mathrm{C}$ and $0.18 \%$ for $\delta^{15} \mathrm{~N}$.

Fatty acid analysis. Data for FAs of both potential prey (Budge et al. 2002) and seals (Beck et al. 2005) have been previously published. Briefly, the lipid from blubber biopsies was quantitatively extracted as described above. FA methyl esters (FAME) were prepared from each extracted lipid sample using an acidic catalyst (the Hilditch method; see Iverson et al. 2001, Budge et al. 2006). Duplicate analyses and identification of FAME were performed using temperatureprogrammed gas-liquid chromatography (GLC) (Iverson et al. 1997b, 2004, Budge et al. 2006). FAs were described by the standard nomenclature of carbon chain length:number of double bonds and location $(n-x)$ of the double bond nearest the terminal methyl group. Individual FAs were expressed as a percentage of total FAs. To improve normality, the proportional data were normalized using a log transformation according to the following equation: $x$ trans $=\ln (x \mathrm{i} / \mathrm{Cr})$, where xtrans is the transformed data, $x i$ is a FA expressed as percent of total FAs, and $c r$ is the percentage of a reference FA, in this case 18:0 (Budge et al. 2002).

Diet estimates. Diet estimates are presented in Beck et al. (2007). Thirteen species were identified in grey seal diet estimates occurring at $>1 \%$ on average (Table 1). The proportional diet data were normalized using a log transformation. Fishes and invertebrates appearing in QFASA estimates were classified as pelagic or benthic based on previous knowledge of feeding habits (Scott \& Scott 1988, Sherwood \& Rose 2005). Trophic levels of fish and invertebrate prey that comprised grey seal diet estimates were also derived from the literature and an online database (FishBase; Froese \& Pauly 2007). For individual grey seals, we summed the proportions of each pelagic species (Table 1) estimated in the diet to obtain the total percentage of pelagic prey. The trophic level of each seal was calculated by taking the weighted average of the proportion of a particular prey item in the diet, multiplied by the average trophic level of that prey as determined independently from the literature. 
Statistical analysis. For both prey and seals, we only used FAs measured at $>0.5$ mass percent of total FA (Iverson et al. 2004, Budge et al. 2006). Transformed FA data were subjected to principal component analyses (PCA) to reduce multi-colinearity and generate independent principal components that could be used as independent variables in subsequent regression analyses to evaluate their relationship with $\delta^{13} \mathrm{C}$.

Only components having eigenvalues $>1$ or accounting for at least $5 \%$ of the total variance were retained. To generate PCA scores for prey, sample size was augmented $(n=579)$ by including additional individuals of the same species from the Scotian Shelf Prey Base, sampled from the same areas and from the same time period (data from Budge et al. 2002). Similarly, grey seal sample size was augmented $(n=529)$ by including additional individuals (data from Beck et al. 2005). Increasing the sample sizes for both prey and grey seals ensured homogeneity of the correlation matrices. We also fit a linear regression to evaluate the relationship between $\delta^{13} \mathrm{C}$ and total percentage of pelagic prey species estimated in the diet. Because sex-specific seasonal differences have been found in SI levels, FA signatures and diets, we conducted separate analyses for males and females using a general linear model (GLM) procedure to test for the effect of sampling time on the relationship between $\delta^{13} \mathrm{C}$ and total percentage of pelagics estimated in the diet.

We also fit a linear regression to evaluate the relationship between $\delta^{15} \mathrm{~N}$ and the estimated trophic level of the diet. It is known that baseline values of $\delta^{15} \mathrm{~N}$ vary between benthic and pelagic systems such that organ-

Table 1. Main system (benthic/pelagic) and trophic levels derived from literature and online resources for main constituents ( $>1 \%$ on average) of grey seal Halichoerus grypus diets estimated by quantitative fatty acid signature analysis

\begin{tabular}{|lcc|}
\hline Diet item & Average contribution (\%) & Trophic level \\
\hline Pelagic & & \\
Capelin & 1.2 & 3.2 \\
Herring & 2.4 & 3.3 \\
Lumpfish & 1.6 & 3.5 \\
Redfish small & 12.8 & 3.5 \\
Sandlance large & 36.9 & 3.2 \\
Sandlance small & 5.1 & 3.0 \\
Benthic & & \\
Pollock large & 1.1 & 4.5 \\
Pollock small & 12.7 & 4.0 \\
Redfish large & 17.3 & 4.5 \\
Snakeblenny & 1.1 & 4.0 \\
Thorny skate & 1.1 & 4.5 \\
Turbot & 2.2 & 4.5 \\
Witchflounder & 3.7 & 3.5 \\
\hline
\end{tabular}

isms at equivalent trophic levels have different signatures (Sherwood \& Rose 2005, Tucker et al. 2007). Therefore, we attempted to control for these differences with the $\delta^{13} \mathrm{C}$ signature, by taking the $\delta^{15} \mathrm{~N}: \delta^{13} \mathrm{C}$ ratio. We then fit a regression to evaluate the relationship between estimated trophic level and the $\delta^{15} \mathrm{~N}: \delta^{13} \mathrm{C}$ ratio. PCA, regression and GLM models were fitted in S Plus Version 6.2 (1988, 2003 Insightful Corp.).

\section{RESULTS}

In fish and invertebrate prey, there were 4 significant principal components accounting for $80 \%$ of the variance in FA signatures. Three of these components accounting for $72 \%$ of the variance (Components 1, 2 and 4; Tables $2 \& 3$, Fig. 1) were significant predictors of $\delta^{13} \mathrm{C}\left(F_{3,44}=33.98 ; \mathrm{p}<0.001\right)$.

There also were 4 significant principal components accounting for $85 \%$ of the variance in grey seal Halichoerus grypus FA signatures (Table 4). The first 2 of

Table 3. Weightings of individual fatty acids in principal components for fish and invertebrates which were significantly correlated with $\delta^{13} \mathrm{C}$

\begin{tabular}{|lrrr|}
\hline \multirow{2}{*}{ Fatty acid } & \multicolumn{3}{c}{ Component } \\
\cline { 2 - 3 } & 1 & 2 & \multicolumn{1}{c|}{4} \\
\hline $14: 0$ & 0.900 & -0.204 & -0.186 \\
$16: 0$ & 0.824 & -0.185 & 0.247 \\
$16: 1 \mathrm{n}-7$ & 0.871 & 0.302 & -0.218 \\
$18: 1 \mathrm{n}-11$ & 0.513 & -0.349 & 0.083 \\
$18: 1 \mathrm{n}-9$ & 0.757 & 0.119 & 0.230 \\
$18: 1 \mathrm{n}-7$ & 0.534 & 0.711 & 0.245 \\
$18: 1 \mathrm{n}-5$ & 0.723 & 0.452 & 0.083 \\
$18: 2 \mathrm{n}-6$ & 0.890 & 0.048 & 0.107 \\
$18: 3 \mathrm{n}-3$ & 0.749 & -0.108 & 0.020 \\
$18: 4 \mathrm{n}-3$ & 0.737 & -0.249 & -0.460 \\
$20: 1 \mathrm{n}-11$ & 0.556 & 0.256 & 0.117 \\
$20: 1 \mathrm{n}-9$ & 0.827 & -0.401 & 0.022 \\
$20: 1 \mathrm{n}-7$ & 0.526 & 0.710 & -0.199 \\
$20: 4 \mathrm{n}-6$ & -0.283 & 0.770 & 0.443 \\
$20: 5 \mathrm{n}-3$ & 0.524 & 0.624 & 0.103 \\
$22: 1 \mathrm{n}-11$ & 0.840 & -0.363 & 0.121 \\
$22: 1 \mathrm{n}-9$ & 0.855 & -0.138 & 0.050 \\
$22: 5 \mathrm{n}-3$ & 0.276 & 0.365 & -0.494 \\
$22: 6 \mathrm{n}-3$ & 0.121 & -0.589 & 0.545 \\
$24: 1 \mathrm{n}-9$ & 0.331 & -0.674 & -0.018 \\
\hline
\end{tabular}



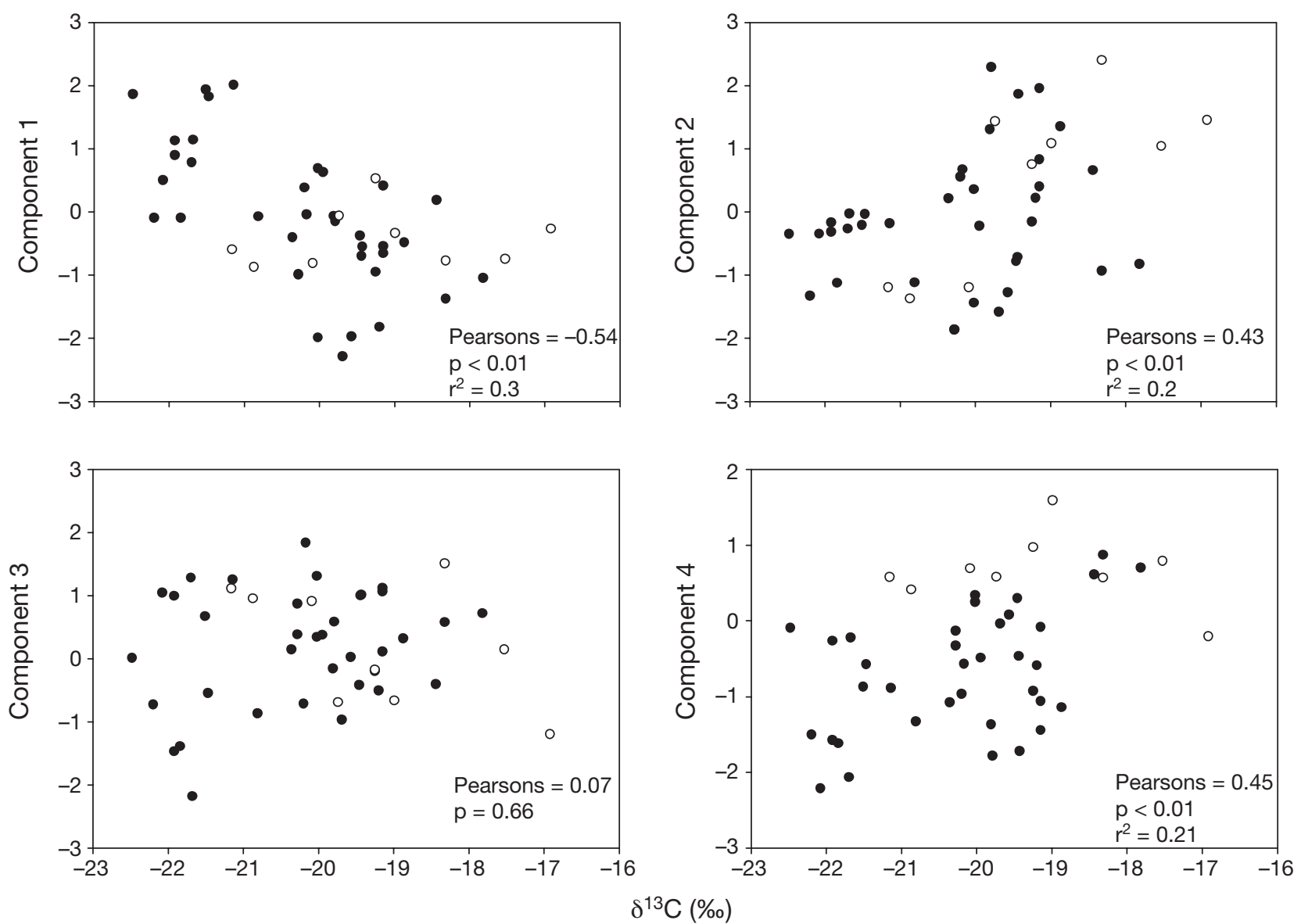

Fig. 1. Principal components of fatty acids and $\delta^{13} \mathrm{C}$ for fish (๑) and invertebrates (O)

those components, which explained $72 \%$ of the variance, were significant predictors of seal $\delta^{13} \mathrm{C}$ (Tables 4 \& 5, Fig. 2).

We found a significant negative relationship between grey seal carbon signature and the proportion of pelagic prey in the diet (Fig. $3 ; F_{1,74}=38.81 ; \mathrm{p}<0.001$ ). There was no effect of sampling time (males: $F_{2,37}=$ 0.89, $\mathrm{p}=0.42$; females: $F_{2,36}=0.92, \mathrm{p}=0.41$ ) in either males or females. There was a significant correlation between the estimated trophic level of the diet and $\delta^{15} \mathrm{~N}\left(F_{1,74}=12.89 ; \mathrm{p}=0.001\right)$. Again, there was no effect of sampling time (males: $F_{2,37}=0.24, \mathrm{p}=0.79$; females: $F_{2,36}=0.92, \mathrm{p}=0.41$ ) in either males or females. There was also a significant correlation between trophic level estimated from FA signatures and the $\delta^{15} \mathrm{~N}: \delta^{13} \mathrm{C}$ ratio (Fig. $4 ; F_{1,74}=26.79 ; \mathrm{p}<0.001$ ).

\section{DISCUSSION}

It is well established that both the FA composition of lipid depots and SI values of lipid-free tissues are indicative of diet. Recently, Iverson et al. (2004) devel- oped a statistical model to estimate the proportions of prey species in the diet by comparing the FA signatures of predators with those of potential prey. This model was validated in feeding experiments on captive animals and by comparison to prey consumption by free-ranging harbour seals Phoca vitulina, recorded with the use of an animal-borne video system (Crittercam) (Iverson et al. 2004). However, with any new method, further testing using field data is desirable. Concurrent sampling of individual predators for both SIs and FAs provide one such independent test.

Both FAs and SIs are known to represent the assimilated portion of a consumer's diet. Consequently, consumption of fish and invertebrates species are independently identified by both their FA profiles (Iverson et al. 1997a,b, Budge et al. 2002) and their SI signatures (Lesage et al. 2001, Sherwood \& Rose 2005, Tucker et al. 2007). Moreover, we have demonstrated that both in a number of prey species and in grey seals Halichoerus grypus there are significant correlations between FA signatures and carbon isotope values. $\delta^{13} \mathrm{C}$ is indicative of carbon source due to various physical and biological pro- 
Table 4. Significant principal components for fatty acid signatures of grey seals, and the coefficients from a multiple regression with $\delta^{13} \mathrm{C}$

\begin{tabular}{|lcccrrrr|}
\hline $\begin{array}{l}\text { Compo- } \\
\text { nent }\end{array}$ & $\begin{array}{c}\text { Eigen- } \\
\text { value }\end{array}$ & $\begin{array}{c}\text { Variance } \\
\text { explained (\%) }\end{array}$ & $\begin{array}{c}\text { Cumulative } \\
\text { variance }\end{array}$ & $\begin{array}{c}\text { Coefficient } \\
\text { B }\end{array}$ & $t$ & $\mathrm{p}$ \\
\hline 1 & 13.95 & 55.79 & 55.79 & -0.395 & -4.57 & 0.000 \\
2 & 3.96 & 15.83 & 71.62 & 0.245 & 2.89 & 0.006 \\
3 & 2.23 & 8.90 & 80.53 & 0.058 & 0.76 & 0.454 \\
4 & 1.20 & 4.80 & 85.33 & 0.159 & 1.83 & 0.074 \\
\hline
\end{tabular}

Table 5. Weightings of individual fatty acids in principal components for grey seals which were significantly correlated with $\delta^{13} \mathrm{C}$

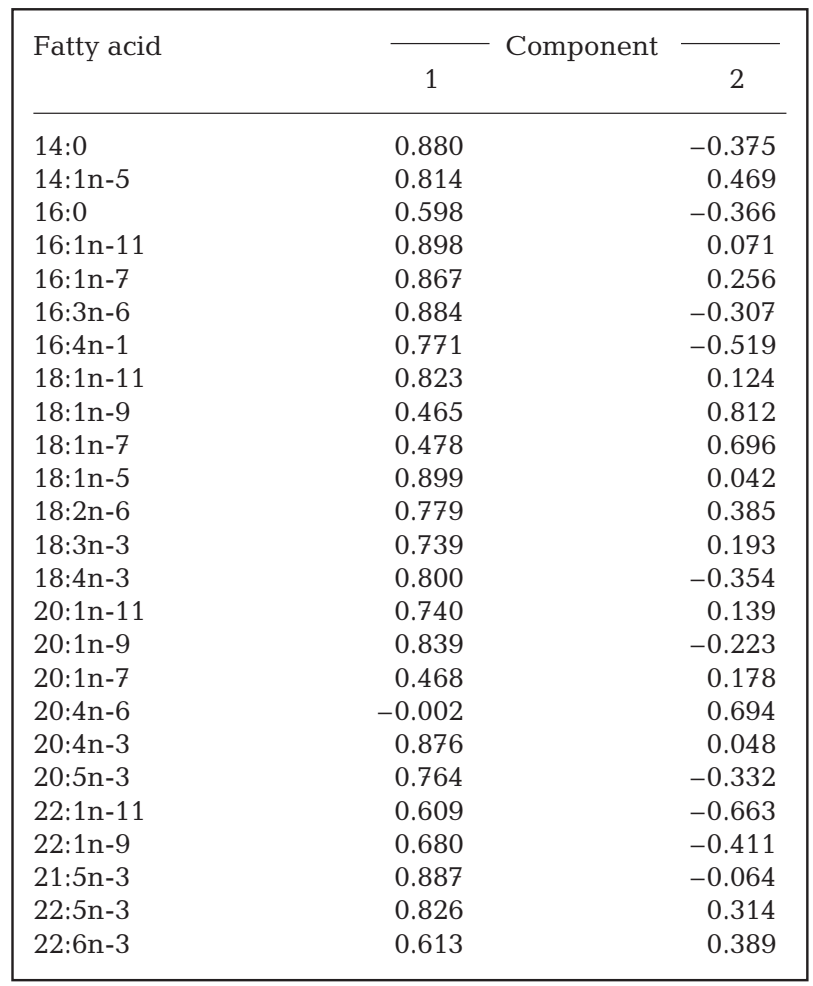

cesses at the base of the food web (Post 2002). Certain FAs are found in greater abundance in particular organisms and systems (Budge et al. 2002, 2006). Components from PCA scores are weighted heavily by FAs that are known to be strongly associated with both pelagic and benthic systems. For example, there are negative relationships between $\delta^{13} \mathrm{C}$ and the first principle component for both fish and seals. Both of the first components are weighted by 14:0, 22:1n-11, 20:1n-9, 18:2n-6, 18:3n-3 and 18:4n-3 (Tables $3 \&$ 5). These FAs are found in elevated proportions in zooplankton, specifically copepod lipids (Graeve et al. 1994), and variation in levels of these FAs, particularly 22:1n-11and 20:1n-9, likely reflects high amounts of zooplankton in the diets of pelagic species such as herring and capelin (Budge et al. 2002; diet data summarized in Froese \& Pauly 2007). Recall that the carbon signature becomes more positive from pelagic to benthic species. Both of the second components are positively correlated with $\delta^{13} \mathrm{C}$ and are weighted by $18: 1 n-7$ and 20:4n-6 (Tables 3 \& 5). These FAs are found in high concentrations in benthic diatoms and, subsequently, in benthic invertebrates and fish (Budge et al. 2002, Käkelä et al. 2005).

Although we found significant correlations between FAs and $\delta^{13} \mathrm{C}$, those relationships explained a relatively small amount of the observed variability. PCA reduced the number of FA variables from 39 to 4 for each of the prey species and grey seals. These new variables accounted for most of the variance in the data (72 to $80 \%$ ). However, one characteristic of PCA in this context is that the mixture of FAs identified as a principal component is constructed using only covariate information, without regard to the relationship between the FAs and their dietary origin. This may contribute to error in regressions with $\delta^{13} \mathrm{C}$, since component scores may not be maximized along the same diet dimension represented by $\delta^{13} \mathrm{C}$. Significant component scores were weighted by specific FAs characteristic of benthic/pelagic sources, suggesting that they are likely similar, but not necessarily equivalent, to $\delta^{13} \mathrm{C}$. Nevertheless, we did find strong significant correlations (Pearson's correlation: range 0.31 to 0.74 ) between $\delta^{13} \mathrm{C}$ and individual FA biomarkers (Tucker 2007), strengthening our conclusion about the convergence between these 2 independent methods of inferring diet.

$\delta^{15} \mathrm{~N}$ is indicative of relative trophic level, given that an organism's signature becomes enriched with every transfer up the food chain. This is due to selective retention of the heavier isotope relative to the lighter isotope within consumers. There is no analogous stepwise trophic pattern for FAs because consumers, with little to no capacity for de novo biosynthesis, assimilate FAs roughly in proportion to their presence in the diet (Iverson et al. 2004, Budge et al. 2006). The trophic level of a consumer represents the weighted average of the trophic levels of its prey. Therefore, it follows that the trophic level derived from an independent estimate of diet is known to match the $\delta^{15} \mathrm{~N}$ signature of a consumer (Vander Zanden et al. 1997).

SIs (Tucker et al. 2007) and qualitative analysis of FA signatures (Beck et al. 2005) of grey seals reveal similar qualitative patterns in diet. Both approaches have found evidence for sex, ontogenetic and temporal variation in diets, as well as a high degree of individual specialization. We found significant correlations between diet composition estimated from blubber FAs 

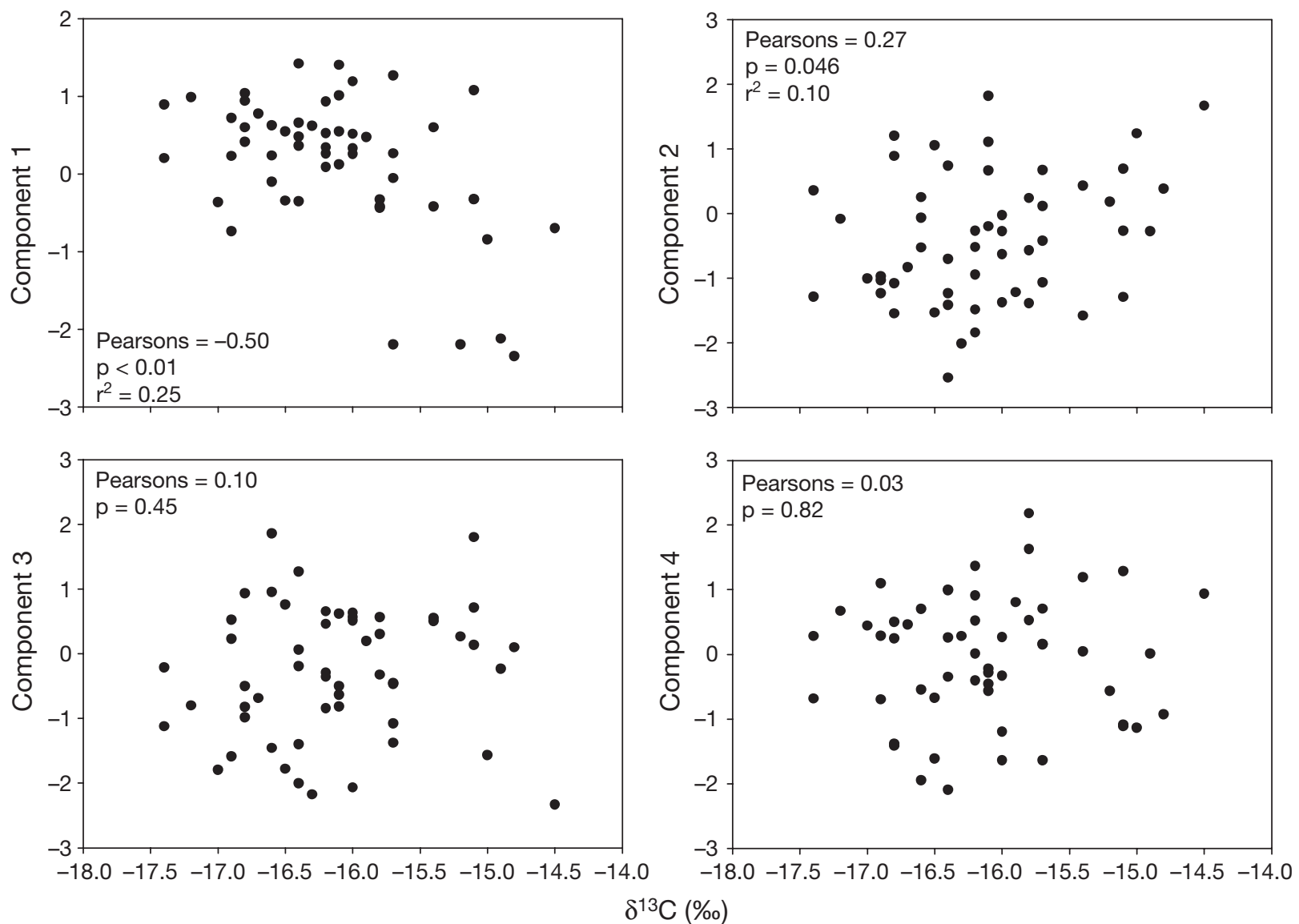

Fig. 2. Principal components of fatty acids, and $\delta^{13} \mathrm{C}$ for grey seals

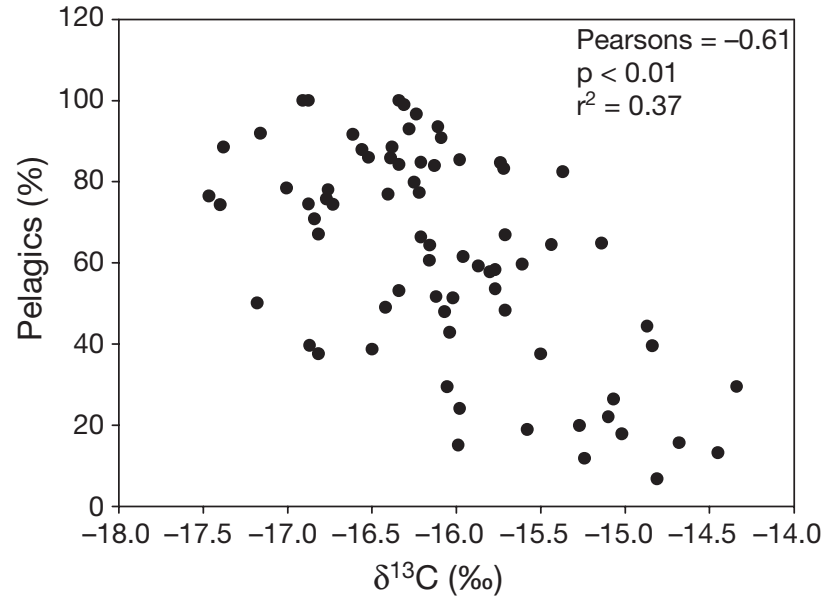

Fig. 3. $\delta^{13} \mathrm{C}$ for grey seals, and total pelagics in the diet $(\%)$

(Beck et al. 2007) and the stable-carbon and stablenitrogen isotope signatures generated from a skin sample from the same animal (Tucker et al. 2007). This was in terms of both the main carbon source of the diet and the trophic level. We found no effect of season, suggesting that there are no temporal effects influencing diet interpretation by either method or the relation- ship between the 2 methods. Nevertheless, the correlations explained a relatively small amount of the observed variability between methods.

We think there are several reasons for this degree of error. First, the temporal scale that each biochemical approach represents is somewhat unclear, and this undoubtedly contributes to the weakness of the correlation. Turnover of SIs varies with the metabolic activity of the tissue sampled (Tieszen et al. 1983, Hobson \& Clark 1992, Hobson 1993). Therefore, tissues with high turnover rates provide dietary information assimilated from recent feeding events, while tissues with slower turnover rates indicate feeding from more distant time periods. Thus, changes in diet can take anywhere from a few days to many weeks to appear in an animal's tissue. The isotopic measurement of several tissues from the same individual can provide short-, intermediateand long-term dietary information (e.g. Hobson 1993). In addition, it is thought that the isotopic analysis of metabolically inactive tissues (e.g. hair, skin, whiskers, claws, feathers and baleen) reflect the diet of individuals only during the period of growth (Schell et al. 1989, Hobson et al. 1996). There is very little information on isotopic turnover rates for mammalian tissues. How- 


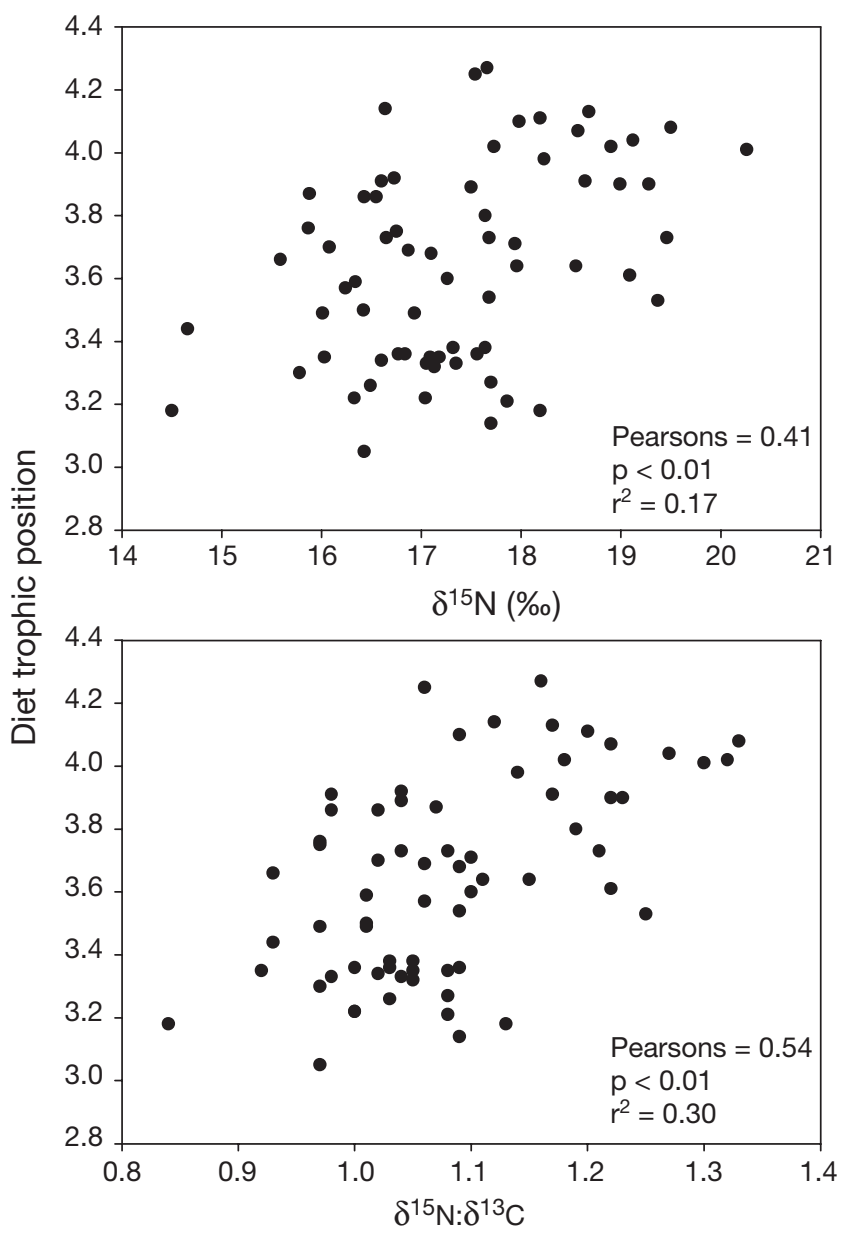

Fig. 4. $\delta^{15} \mathrm{~N}$ and $\delta^{15} \mathrm{~N}: \delta^{13} \mathrm{C}$ ratio for grey seals, and trophic level of the diet $(\%)$

ever, by coupling literature values of protein synthesis rates and carbon isotope turnover rates in various mammal tissues, Kurle \& Worthy (2002) estimated that the time in which dietary information became incorporated into fur seal skin was on the order of 3 to 4 mo prior to sampling. Thus, if a similar time scale applies to grey seals, the isotope signatures mainly reflect the prey consumed 3 mo previous to sampling.

Similarly, FA analyses of different tissues (e.g. adipose tissue, blubber, milk and blood) provide insights into diet over different temporal scales (reviewed in Budge et al. 2006). We analyzed the FA composition of grey seal blubber. Grey seals undergo 2 periods of fasting and subsequent replenishment over an annual cycle (e.g. Beck et al. 2003). Seals deplete their blubber reserves during reproduction and again during the moult months later. Thus, the FA composition of grey seal blubber sampled early in the breeding season is thought to mainly reflect feeding over the course of several months (Beck et al. 2005), with little contribution from feeding earlier in the year. In feeding exper- iments on seals, it has been noted that the appearance of new dietary FA is evident within 1 to $2 \mathrm{wk}$ of a switch in diet (Kirsch et al. 2000, Cooper 2004, Iverson et al. 2004). Therefore, it is assumed that FA signatures of seal blubber represent a dynamic integration of the diet over weeks to months.

Due to sampling constraints, our study analyzed samples of grey seal skin. Isotope values then likely reflect diets assimilated 3 to 4 mo prior, and not the entire diet assimilated over the course of those 3 to 4 mo. On the other hand, FAs in blubber likely integrate diets assimilated during those same months and perhaps in previous months. Therefore, while there is overlap, the 2 approaches do not necessarily report diets over the exact same time scale. Although there is undoubtedly overlap in the time scales of assimilation of the diet of the tissues sampled for FAs and SIs, it is also likely that they are not equivalent, and thus we should not expect them to both reflect previous diets in the same manner. Furthermore, individual variation in fractionation (the relationship between predator and diet signatures) has been noted for both SIs (e.g. Hobson et al. 1996) and FAs (e.g. Iverson et al. 2004) and likely also contributes to error. These 2 approaches represent the assimilated signature from multiple dietary sources. Prey species with more similar diets have more similar stable isotope signatures, making it difficult to tease apart specific contributions to a consumer's diet. On the other hand, because of the large number of FAs analyzed, FA signatures are far more powerful in defining and identifying inter-specific differences, despite similarities in respective diets (Budge et al. 2002). The difference in resolution between these 2 methods is also likely another source of error. In addition, there is some evidence for variation in baseline SI values (Lesage et al. 2001) across the ecosystems where seals may forage (St Lawrence Estuary, Gulf of St Lawrence, the Scotian Shelf). This may then also be a source of noise in the SI values.

Our main goal was to provide corroboration for QFASA-derived diet estimates, as this approach is being increasingly applied to quantify proportional prey inputs of free-ranging predators (e.g. Iverson et al. 2004, Beck et al. 2007). We have shown 2 lines of evidence for the convergence of SI and FA estimates of diet. First, in fish, invertebrates and grey seals, principal components derived from FA signatures are correlated to the stable-carbon isotope signature of the same species. Second, both the estimated portion of pelagic prey and the trophic level of the diet derived from the quantitative analysis of FA signatures of individual seals are positively correlated with the $\delta^{13} \mathrm{C}$ and $\delta^{15} \mathrm{~N}$ signatures in those same individuals. The application of SI mixing models (Phillips et al. 2005) might improve the correspondence between the 2 types of 
tracers. However, this would require a considerably larger isotope prey base. Unfortunately, we selected the fish and invertebrate species for SI analysis well prior to the estimation of grey seal diets by QFASA. Exact duplication of prey species would facilitate a more direct approach. In addition, since the measurement of several tissues for SIs can provide a range of temporal dietary information (e.g. Hobson 1993, Hobson et al. 1996), this could result in greater overlap in the time scales of assimilated dietary information of these 2 biochemical methods.

Acknowledgements. We thank Debbie Austin, Carrie Beck, Daryl Boness, Susanne Budge, Shelley Lang, Damian Lidgard and Jim McMillan for their assistance in the field. We also thank Gerry Forbes, Officer-in-Charge of the Atmospheric Environmental Service, for logistical support on Sable Island. We thank Carrie Beck for providing fatty acid data and diet estimates for grey seals. Wade Blanchard provided valuable advice on statistical analysis. Susanne Budge and 2 anonymous referees provided helpful comments on earlier drafts of the manuscript. This study was supported by Natural Sciences and Engineering Research Council (NSERC) Canada research grants to W.D.B. and S.J.I. and by the Department of Fisheries and Oceans, Canada. All procedures used on grey seals in this study were in accordance with the principles and guidelines of the Canadian Council on Animal Care.

\section{LITERATURE CITED}

Bearhop S, Adams CE, Waldron S, Fuller RA, Macleod H (2004) Determining trophic niche width: a novel approach using stable isotope analysis. J Anim Ecol 73:1007-1012

Beck CA, Bowen WD, Iverson SJ (2003) Sex differences in the seasonal patterns of energy storage and expenditure in a phocid seal. J Anim Ecol 72:280-291

Beck CA, Iverson SJ, Bowen WD (2005) Blubber fatty acids of gray seals reveal sex differences in the diet of a sizedimorphic marine carnivore. Can J Zool 83:377-388

Beck CA, Iverson SJ, Bowen WD, Blanchard W (2007) Sex differences in grey seal diet reflect seasonal variation in foraging behaviour and reproductive expenditure: evidence from quantitative fatty acid signature analysis. J Anim Ecol 76:490-502

Bowen WD, Siniff DB (1999) Distribution, population biology, and feeding ecology of marine mammals. In: Reynolds JE III, Rommel SA (eds) Biology of marine mammals. Smithsonian Institution Press, Washington, DC, p 423-484

Bowen WD, Stobo WT, Smith SJ (1992) Mass changes of grey seal (Halichoerus grypus) pups on Sable Island: differential maternal investment reconsidered. J Zool Lond 227:607-622

Bowen WD, Lawson JW, Beck B (1993) Seasonal and geographic variation in the species composition and size of prey consumed by grey seals (Halichoerus grypus) on the Scotian shelf. Can J Fish Aquat Sci 50:1768-1778

Bowen WD, Beck CA, Iverson SJ, Austin D, McMillan JI (2006) Linking predator foraging behaviour and diet with variability in continental shelf ecosystems: grey seals of eastern Canada. Top predators in marine ecosystems. Cambridge University Press, p 63-89

Budge SM, Iverson SJ, Bowen WD, Ackman RG (2002) Among- and within-species variability in fatty acid signatures of marine fish and invertebrates on the Scotian Shelf,
Georges Bank, and southern Gulf of St. Lawrence. Can J Fish Aquat Sci 59:886-898

Budge S, Iverson S, Koopman H (2006) Studying trophic ecology in marine ecosystems using fatty acids: a primer on analysis and interpretation. Mar Mamm Sci 22:759-801

Cooper MH (2004) Fatty acid metabolism in marine carnivores: implications for quantitative estimation of predator diets. $\mathrm{PhD}$ thesis, Dalhousie University, Halifax

Cooper MH, Iverson SJ, Heras H (2005) Dynamics of blood chylomicron fatty acids in a marine carnivore: implications for lipid metabolism and quantitative estimation of predator diets. J Comp Physiol B 175:133-145

Davenport SR, Bax NJ (2002) A trophic study of a marine ecosystem off southeastern Australia using stable isotopes of carbon and nitrogen. Can J Fish Aquat Sci 59:514-530

France RL, Peters RH (1997) Ecosystem differences in the trophic enrichment of $13 \mathrm{C}$ in aquatic food webs. Can J Fish Aquat Sci 54:1255-1258

Froese R, Pauly D (2007) FishBase. Available at www. fishbase.org

Graeve M, Kattner G, Hagen W (1994) Diet-induced changes in the fatty acid composition of Arctic herbivorous copepods: experimental evidence of trophic markers. J Exp Mar Biol Ecol 182:97-110

Hobson KA (1993) Trophic relationships among high Arctic seabirds: insights from tissue-dependent stable-isotope models. Mar Ecol Prog Ser 95:7-18

Hobson KA, Clark RG (1992) Assessing avian diets using stable isotopes. I. Turnover of $\delta^{13} \mathrm{C}$ in tissues. Condor 94: 181-188

Hobson KA, Welch HE (1992) Determination of trophic relationships within a high Arctic marine food web using $\delta^{13} \mathrm{C}$ and $\delta^{15} \mathrm{~N}$ analysis. Mar Ecol Prog Ser 84:9-18

Hobson KA, Piatt JF, Pitocchelli J (1994) Using stable isotopes to determine seabird trophic relationships. J Anim Ecol 63:786-798

Hobson KA, Schell DM, Renouf D, Noseworthy E (1996) Stable carbon and nitrogen isotopic fractionation between diet and tissues of captive seals: implications for dietary reconstructions involving marine mammals. Can J Fish Aquat Sci 53:528-533

Iverson SJ (1993) Milk secretion in marine mammals in relation to foraging: Can milk fatty acids predict diet? Symp Zool Soc Lond 66:263-291

Iverson SJ, Frost KJ, Lowry LF (1997a) Fatty acid signatures reveal fine scale structure of foraging distribution of harbor seals and their prey in Prince William Sound, Alaska. Mar Ecol Prog Ser 151:255-271

Iverson SJ, Arnould JPY, Boyd IL (1997b) Milk fatty acid signatures indicate both minor and major shifts in the diet of lactating Antarctic fur seals. Can J Zool 75:188-198

Iverson SJ, Lang SL, Cooper MH (2001) Comparison of the Bligh and Dyer and Folch methods for total lipid determination in a broad range of marine tissue. Lipids 36:1283-1287

Iverson SJ, Field C, Bowen WD, Blanchard W (2004) Quantitative fatty acid signature analysis: a new method of estimating predator diets. Ecol Monogr 74:211-235

Jobling M (1987) Marine mammal faecal samples as indicators of prey importance-a source of error in bioenergetics studies. Sarsia 72: 255-260

Jobling M, Breiby A (1986) The use and abuse of fish otoliths in studies of feeding habits of marine piscivores. Sarsia 71: 265-274

Käkelä R, Käkelä A, Kahle S, Becker PH, Kelly A, Furness RW (2005) Fatty acid signatures in plasma of captive herring gulls as indicators of demersal or pelagic fish diet. Mar Ecol Prog Ser 293:191-200 
Kelly JF (2000) Stable isotopes of nitrogen and carbon in the study of avian and mammalian trophic ecology. Can J Zool 78:1-27

Kirsch PE, Iverson SJ, Bowen WD (2000) Effect of a low-fat diet on body composition and blubber fatty acids of captive juvenile harp seals (Phoca groenlandica). Physiol Biochem Zool 73:45-59

Kurle CM, Worthy GAJ (2001) Stable isotope assessment of temporal and geographic differences in feeding ecology of northern fur seals (Callorhinus ursinus) and their prey. Oecologia 126:254-265

Kurle CM, Worthy GAJ (2002) Stable nitrogen and carbon isotope ratios in multiple tissues of northern fur seal Callorhinus ursinus: implications for dietary and migratory reconstructions. Mar Ecol Prog Ser 236:289-300

Lesage V, Hammill MO, Kovacs KM (2001) Marine mammals and the community structure of the Estuary and Gulf of St Lawrence, Canada: evidence from stable isotope analysis. Mar Ecol Prog Ser 210:203-221

Lesage V, Hammill MO, Kovacs KM (2002) Diet-tissue fractionation of stable carbon and nitrogen isotopes in phocid seals. Mar Mamm Sci 18:182-193

Phillips DL, Newsome SD, Gregg JW (2005) Combining sources in stable isotope mixing models: alternative methods. Oecologia 144:520-527

Post DM (2002) Using stable isotopes to estimate trophic position: models, methods and assumptions. Ecology 83:703-718

Schell DM, Saupe SM, Haubenstock N (1989) Bowhead

Editorial responsibility: Howard Browman,

Storebø, Norway whale (Balaena mysticetus) growth and feeding as estimated by $\delta^{13} \mathrm{C}$ techniques. Mar Biol 103:433-443

Scott WB, Scott MG (1988) Atlantic fishes of Canada. Can Bull Fish Aquat Sci 219:1-731

Sherwood GD, Rose GA (2005) Stable isotope analysis of some representative fish and invertebrates of the Newfoundland and Labrador continental shelf food web. Estuar Coast Shelf Sci 63:537-549

Smith SJ, Iverson SJ, Bowen WD (1997) Analysis of fatty acid signatures using classification trees: a new tool for investigating the foraging ecology of seals. Can J Fish Aquat Sci 54:1377-1386

Tieszen LL, Boutton TW, Tesdahl KG, Slade NA (1983) Fractionation and turnover of stable carbon isotopes in animal tissues: implications for $\delta^{13} \mathrm{C}$ analysis of diet. Oecologia 57: $32-37$

Tucker S (2007) Defining sources of variation in diets of northern phocids using stable isotopes and quantitative fatty acid signature analysis. $\mathrm{PhD}$ thesis, Dalhousie University, Halifax

Tucker S, Bowen WD, Iverson SJ (2007) Dimensions of diet segregation in a marine carnivore, the grey seal, revealed through stable isotopes of carbon $\left(\delta^{13} \mathrm{C}\right)$ and nitrogen $\left(\delta^{15} \mathrm{~N}\right)$. Mar Ecol Prog Ser 339:271-282

Vander Zanden MJ, Cabana G, Rasmussen JB (1997) Comparing trophic position of freshwater fish calculated using stable nitrogen ratios and literature dietary data. Can J Fish Aquat Sci 54:1142-1158

Submitted: May 18, 2007; Accepted: September 23, 2007 Proofs received from author(s): January 12, 2008 